\title{
UK underestimates cost of Trident deterrent
}

AT present the British deterrent force consists of a fleet of four submarines armed with Polaris A-3 missiles that were supplied by the United States on terms well below cost in the 1960s, a largesse not likely to be repeated. The timing of the decision on renewing the deterrent is forced by the expected deterioration of the Polaris submarine hulls after 25 years of service, that is, by about 1993. Given the lead time needed for development and production of a new submarine, a decision is necessary soon. Postponement might mean abandoning the submarine-based deterrent, although choice of a different technology, such as air-launched cruise missiles, would imply a different timetable.

Coincidentally, NATO has just decided to push ahead with the modernisation of its 'theatre' nuclear weapons by deploying US Pershing II and Ground Launched Cruise Missiles (GLCMs); 160 of the latter will be based in England. Although in one sense these theatre missiles could be regarded as 'strategic' weapons - since like Polaris they will be able to reach targets within the Soviet Union - from an operational and financial perspective they are quite different. A new independent British deterrent force will be paid for by Britain, and, although it will be integrated into NATO forces, Britain will reserve the right to fire the missiles on its own. The theatre nuclear missiles will be assigned to NATO, but will be paid for by the United States and be under US control.

The decision to replace the Polaris fleet is first and foremost a political decision, based implicitly (for there has been no public discussion) on a certain view of Britain's status in the world and its relations with the US and its other NATO allies. The decision also has economic and technological consequences.

How much will a new submarine-based nuclear deterrent cost the British taxpayer? The operating costs of the Polaris fleet are not particularly large - only $£ 126$ million out of a total defence budget of $£ 8,558$ million in 1979 - but the investment in the design and production of a new submarine and missile will be heavy. Ian Smart in his 1977 Chatham House paper 'The Future of the British Nuclear Deterrent' estimated the cost of a replacement programme at $£ 2,245-2,925$ million at 1976 prices. That figure, swollen by inflation, stands now at
Britain has decided to renew its independent nuclear deterrent, probably by buying the submarine-launched Trident C-4 missile from the United States. Judith Reppy, Visiting Fellow at the Science Policy Research Unit at the University of Sussex, argues that this would be a questionable decision on economic grounds

perhaps $£ 5,000$ million for five submarines and their nuclear missiles.

There is reason, however, to question whether even this sum will pay the costs of replacing the Polaris fleet. The United States expects to spend over $\$ 23,000$ million (about $£ 10,500$ million) on a fleet of thirteen new submarines, and missiles; $62 \%$ of this is attributable to the cost of the submarine (see 'Trident - the US Experience: ADIU Report, Vol. 1 No 4, December 1979). The US Trident submarine is a huge boat, 560 feet long, and it has proved very expensive to build, costing over $\$ 1600$ million ( $£ 730$ million) per boat. But even though Britain would surely choose a more modest design, it is still likely that it would cost more than Smart's estimate. That estimate allocated only $40 \%$ of the total programme costs to the submarine, or roughly $£ 240$ million per boat (1976 prices). The US figure suggests that is too low.

British shipbuilding capacity has shrunk since the Polaris submarines were

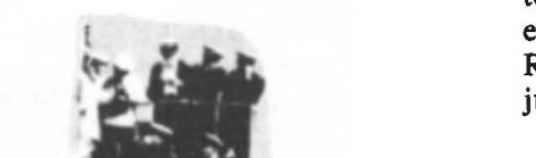

constructed in the 1960 s, and only the Vickers Barrow yard now builds nuclear submarines. To build the new submarines at Barrow would take up capacity needed for other Navy programmes, whereas investing in new capacity elsewhere would entail costs not included in the Smart estimate. It can be argued that to invest in additional specialised industrial capacity to build five units of a product for which there is no other market would be economic folly.

Beyond these budgetary costs lie important opportunity costs, both with respect to other categories of public spending, such as education and health, and within the defence category itself. The share of the budget required for submarine design and construction will almost certainly pinch other elements of defence spending. Considering the emphasis placed on shortages of conventional weapons in the government's assessment of the military balance, it is perhaps surprising that tanks or air defence weapons are not considered a more urgent priority.

Given the large sums of money involved, the Trident decision also represents an important element in government funding for new technology. It is likely that the government will purchase the missiles from the United States, but develop and produce the warheads in Britain as was done for Polaris. Expertise in the technology of multiple independently targeted re-entry vehicles (MIRVs) will be acquired from the US. These capabilities, however, are not likely to spread into the civilian economy; they are too specialised for direct transfer, and the military market itself is so narrow that further internally-generated technological growth is not probable. The expenditure of more than $£ 1,000$ million on $R$ \& $D$ for the Trident missile must be justified solely in military terms.

But the most disturbing aspect of the government's decision has been the absence of any public debate on the validity of the arguments for renewing the independent deterrent and the advantages and drawbacks of the various technological options. The public will pay the costs; it deserves a chance to consider whether it wants the programme.

Polaris submarine: replacements are needed for the 1990s.

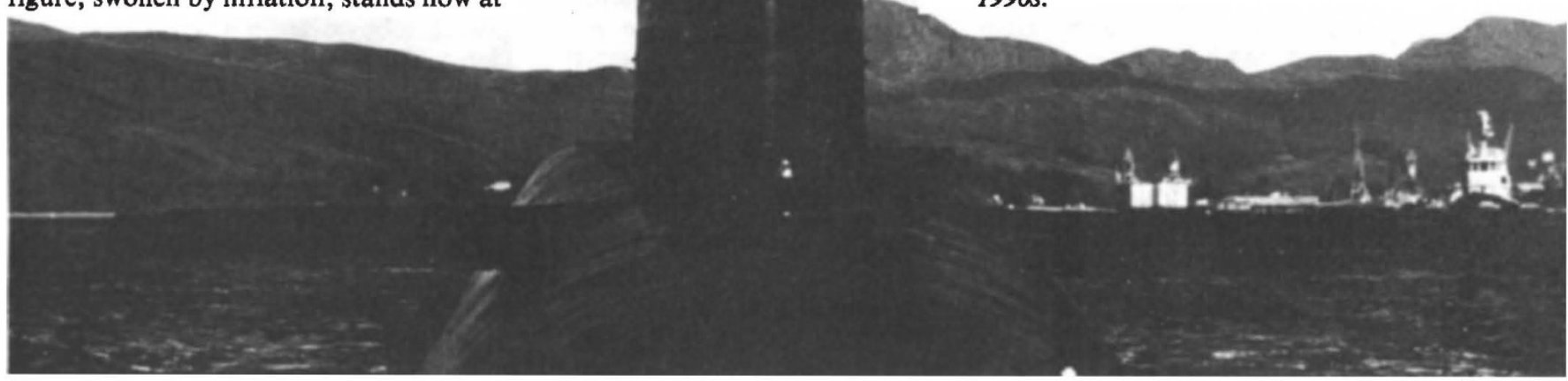

